ISSN: 2089- 7553

\title{
ALIH FUNGSI TANAH PERTANIAN DAN AKIBAT HUKUMNYA.
}

\author{
Oleh: I Komang Darman*
}

\begin{abstract}
ABSTRAK
Kebijakan dalam peraturan Perundang-undangan yang berkaitan dengan masalah pengendalian alih fungsi tanah pertanian menjadi Kawasan Perumahaan sudah banyak dibuat, namum demikian implementasi pelaksanaan peraturan tersebut kurang efektif karena tidak didukung dengan data tanah pertanian pangan berkelanjutan yang dilindungi dan sikap proaktif sehingga alih fungsi tanah pertanian terus terjadi.

Akibat hukum alih fungsi tanah pertanian pangan berkelanjuatan berdasarkan Undang-undang Nomor 41 tahun 2009 Tentang Perlindungan Lahan Pertanian Pangan Berkelanjutan, yang menjelaskan bagi setiap orang yang memiliki Lahan Pertanian Pangan Berkelanjutan dan kemudian menjual atau mengalihkan hak miliknya, maka fungsi dari pada tanah tersebut tidak boleh diubah. Jika mengubah dan menyebabkan saluran irigasi, infrastruktur serta mengurangi kesuburan tanah maka berdasarkan pasal 51 ayat (2), orang tersebut berkewajiban untuk merehabilitasi lahan, dengan cara mpenyempurnaan sarana dan prasarana mencakup irigasi, jalan usaha tani, ketersedian alat pengolahan tanah mekanis dan membangun irigasi kembali agar tanah pertanian produktif.
\end{abstract}

Kata Kunci: Alih Fungsi Tanah, Kawasan Perumahan, Akibat Hukum.

\section{PENDAHULUAN}

Perumahan dan permukiman merupakan salah satu kebutuhan pokok manusia. Sebagaimana diamanatkan dalam Undang-Undang Dasar (UUD) 1945 Pasal 28H UUD 1945, bahwa rumah adalah salah satu hak dasar rakyat dan oleh karena itu setiap Warga Negara berhak untuk bertempat tinggal dan mendapat lingkungan hidup yang baik dan sehat. Selain itu rumah juga merupakan kebutuhan dasar manusia dalam 
meningkatkan harkat, martabat, mutu kehidupan dan penghidupan, serta sebagai pencerminan diri pribadi dalam upaya peningkatan taraf hidup, serta pembentukan watak, karakter dan kepribadian bangsa.

Rumah adalah salah satu hak rakyat dan oleh karena itu setiap warga negara berhak untuk betempat tinggal dan mendapatkan lingkungan yang baik den sehat, sesuai dengan amanat Undang-undang Nomor 1 Tahun 2011 tentang Perumahan dan Kawasan pemukiman. Pembagunan dan kawasan pemukiman selalu menghadapi permasalahan pertanahan kususnya wilwyah perkotaan, apalagi tanah tersebut adalah Tanah Pertanin Pangan Berkelanjutan yang sudah mendapatkan perlindungan hukum dalam Undang-undang Nomor 41 Tahun 2009 dan sudah dimasukan dalam RTRW Baik Provinsi,Kabupaten dan Kota. Rumah selain berfungsi sebagai tempat tinggal atau hunian dan sebagai asserana pembinaan keluarga yuang mendukung perikehidupan dan penghidupan juga berfungsi sebagai pusat pendidikan keluarga, persemaian budaya dan penyipan generasi muda. Oleh karena itu pengemban perumahan dengan lingkungan yang layak dan sehat merupakan wadah untuk pengembangan sumbser bangsa indonesia dimasa depan.

Kecenderungan pengembangan pertumbuhan penduduk mengarah pada wilayah pinggiran kota sebagai akibat perluasan aktivitas kota. Pusat kota sudah tidak mampu lagi menampung desakan jumlah penduduk. Pertambahan penduduk yang terus meningkat mengindikasikan bahwa perkembangan penduduk menyebar ke arah pinggiran kota (sub-urban) sehingga sebagai konsekuensinya adalah terjadi perubahan guna lahan perkotaan. Untuk memenuhi kebutuhan akan perumahan digunakanlah tanah pertanian untuk pembangunan 
perumahan. Pembangunan perumahan baik yang diusahakan oleh pihak swasta maupun oleh perseorangan untuk pemenuhan akan kebutuhan rumah tinggal.

Terkait persoalan bahwa rumah adalah salah satu hak dasar rakyat dan oleh karena itu setiap Warga Negara berhak untuk bertempat tinggal dan mendapat lingkungan hidup yang baik dan sehat, yang selanjutnya di atur berdasarkan Undang-Undang Nomor 1 Tahun 2011. Pembangunan perumahan dan kawasan permukiman selalu menghadapi permasalahan pertanahan khususnya wilayah perkotaan, apalagi jika tanah tersebut merupakan tanah pertanian yang telah di beri landasan hukum Undang-Undang Nomor 41 Tahun 2009 yang melindungi kawasan pertaniaan pangan berkelanjutan, serta peraturan pelaksananya dan harus mengacu pada RTRW berdasar Undang-Undang Nomor 26 Tahun 2007 dan peraturan perundang-undangan terkaitlainnya.

\section{PENGATURAN ALIH FUNGSI TANAH PERTANIAN MENJADI KAWASAN PERUMAHAN}

\section{Kebijak Pengendalian Alih Fungsi Tanah Pertanian Guna Ketahanan Pangan}

Undang-Undang Nomor 7 Tahun 1996 tentang Pangan menyebutkan bahwa Pangan merupakan hak asasi bagi setiap individu di Indonesia. Oleh karena itu terpenuhinya kebutuhan pangan di dalam suatu negara merupakan hal yang mutlak harus dipenuhi. Selain itu pangan juga memegang kebijakan penting dan strategis di Indonesia berdasar pada pengaruh yang dimilikinya secara sosial, ekonomi, dan politik. Berdasarkan pada Undang-Undang RI Nomor 7 Tahun 1996 tentang Pangan, Ketahanan Pangan adalah suatu kondisi dimana setiap 
individu dan rumah tangga memiliki akses secara fisik, ekonomi, dan ketersediaan pangan yang cukup, aman, serta bergizi untuk memenuhi kebutuhan sesuai dengan seleranya bagi kehidupan yang aktif dan sehat.

Berdasarkan Peraturan Pemerintah Nomor 1 Tahun 2011 Tentang Penetapan dan alih Fungsi Lahan Pertanian Pangan Berkelanjutan diatur bahwa keteria Kawasan Pertanian Pangan Berkelanjuatan:

1. Memilki hamparan lahan dengan dengan luasan tertentu sebagai lahan pertanian pangan berkelanjutan dan/atau lahan cadangan pertanian pangan berkelanjutan dan/atau lahan cadangan pertanian berkelanjuatan; dan

2. Menghasilkan pangan pokok dengan dengan tingkat produksi yang dapat memenuhi kebutuhan pangan sebagian besar masyarakat setempat, kabupaten/kota, dan /atau nasional.

Penetapan keteria teknis dan persyaratan lahan pertanian pangan berkelanjutan di tuangkan dalam pasal 2 Peraturan Mentri Pertanian Nomor: 07/Permentan/OT.140/2/2013 Tentang Pedoman Teknis Keteria Dan Persyaratan Kawasan, Lahan, Dan Lahan Cadangan Pertanian Pangan Berkelanjutan.

"pedoman teknis kriteria dan persyaratan kawasan, lahan, dan cadangan pertanian pangan berkelanjutan sebagaimana dimaksud dalam pasal 1 sebagaimana dasar pemerintah, pemerintah daerah provinsi, pemerintah daerah kabupaten/kota dalam penetapan kawasan, lahan dan lahan cadangan pertanian berkelanjutan".(/Permentan /OT.140/2/2013 pasal 2)

Sehingga dari pedoman teknis keteria teknis dan persyaratan lahan pertanian pangan berkelanjutan bisa di tuangkan ke dalam Peraturan Daerah baik Provinsi Kabupaten/Kota dalam rencana Tata Ruang Wilayahnnya (RTRW), yang menjamin perlindungan dan 
kelangsungan lahan pertanian pangan di wilayah tersebut. Selain itu juga penetapan dan perlindungan tanah pertanian ini merupakan amanat Undang-undang Perlindungan Lahan Pertanian Pangan Berkelanjutan, ditetapkan 16 September 2009. Melalui Undang-undang ini, kawasan dan lahan pertanian pangan ditetapkan (jangka panjang, menengah, dan tahunan) lewat perencanaan kabupaten/kota, provinsi, dan nasional. (Pasal 11-17 Undang-undang RI Nomor .41 Tahun 2009)

\section{Kebijakan Perumahan dan Kawasan Pemukiman.}

Dalam Undang-undang Nomor 1 Tahun 2011 Tentang Perumahan dan Kawasan pemukiman. Perumahan adalah mengcakup rumah, prasarana dan utinitas umum. Tujuannya pembangunan menurut muchin “Orang dapat menepati perumahan yang sehat untuk mendukung kelangsungan dan kesejahtraan sosialnya(Muchin Iman koeswahyono 2013 : 55) oleh karenanya Budiharjo menggungkat hal-hal pokok yang perlu menjadi perhatian dengan pembangunan perumahan, serta mengembangkan Bill Of Right atau hak asasi pemukiman.

Perumahan dan Kawasan Permukiman merupakan perwujudan keberpihakan Pemerintah dalam pemenuhan kebutuhan rumah bagi masyarakat terutama bagi Masyarakat Berpenghasilan Rendah (MBR). Oleh karena itu, Kementerian Perumahan Rakyat yang diberi amanat untuk bertanggung jawab sebagai bagian yang menangani bidang perumahan dan kawasan permukiman

Salah satu sumber daya utama dalam mewujudkan kesejahteraan umum adalah melalui pengelolaan dan pendayagunaan tanah. Tanah dalam wilayah NKRI merupakan salah satu sumber daya utama yang selain memiliki nilai batiniah yang mendalam bagi rakyat Indonesia, juga 
memiliki fungsi yang sangat strategis dalam memenuhi kebutuhan Negara dan rakyat yang semakin meningkat dan beragam, baik di tingkat nasional maupun dalam hubungannya dengan dunia Internasional Oleh karenanya tanah harus dikelola dan dimanfaatkan secara optimal bagi generasi sekarang dan generasi yang akan datang dalam rangka mewujudkan masyarakat adil dan makmur. (Budiharjo, Eko 1997 :67)

Undang-Undang Nomor 1 Tahun 2011 tentang Perumahan dan Permukiman, adalah salah satu bentuk kebijakan sektor perumahan dan kawasan permukiman. Undang-Undang ini menjadi pengganti UndangUndang Nomor 4 Tahun 1992 tentang Perumahan dan Permukiman. Lahirnya Undang-Undang Nomor 1 tahun 2011 tentang perumahan dan Kawasan Permukiman yang terdiri dari 18 BAB dan 167 Pasal merupakan bukti keberpihkan pemerintah terhadap pemenuhan hak akan rumah bagi masyarakat. Terutama, bagi masyarakat berpenghasilan rendah sebagaimana dalam Pasal 50 (1) yang berbunyi: "Setiap orang berhak untuk bertempat tinggal atau menghuni rumah".

Berdasarkan Undang-undang ini, rumah berfungsi sebagai tempat tinggal atau hunian dan sarana pembinaan keluarga yang mendukung perikehidupan dan penghidupan juga mempunyai fungsi sebagai pusat pendidikan keluarga, persemaian budaya, dan penyiapan generasi muda. Kebutuhan rumah bagi masyarakat dapat dilakukan melalui kepemilikan, dengan cara sewa maupun cara lain sesuai peraturan perundang-undangan.

Kemudahan pembangunan dan perolehan rumah bagi masyarakat berpenghasilan rendah, menurut Pasal 54 Ayat (3), adalah dengan memberikan kemudahan berupa pembiayaan, pembangunan prasarana, sarana, dan utilitas umum, subsidi perolehan rumah, stimulan 
rumah swadaya, insentif perpajakan, perizinan, asuransi dan penjaminan penyediaan atanah dan/ atau sertifikasi tanah.

\section{Pengaturan Alih Fungsi Tanah Pertanian Menjadi Kawasan Perumahan}

Alih fungsi merupakan kegiatan perubahan pengunaan tanah dari suatu kegiatan yang menjadi kegiatan lainnya. Pertumbuhan penduduk dan peningkatan kebutuhan tanah untuk kegiatan pembangunan telah menambah struktur kepemilikan dan pengunaan tanah secara terus menerus selain itu untuk memenuhi kebutuhan perumahan dan pemukiman. Alih tanah pertanian juga terjadi secara cepet untuk memenuhi kebutuhan perumahan yang jauh lebih besar. ${ }^{1}$ (Harsono hadi dalam Ali sofyan husen, 1995: 13)

Peranan pembangunan dalam masa-masa sekarang ini, sangatlah dirasakan adanya peningkatan kebutuhan akan tanah untuk keperluan berbagai macam aspek dalam menumbuhkan pembangunan yang merata bagi lapisan masyarakat, terutama pembangunan dibidang fisik baik desa maupun kota. Tanah sebagai modal dasar pembangunan memegang peranan yang sangat penting untuk melaksanakan kegiatan pembangunan, seperti mendirikan gedung sekolah, pelebaran jalan dan lain sebagainya. Akan tetapi banyaknya tanah yang tersedia untuk keperluan pembangunan sangatlah terbatas.

Pranata hukum yang mengatur pengambilan tanah-tanah penduduk untuk keperluan pembangunan, dilakukan dengan melalui: 1. Pengadaan tanah. Pengadaan tanah ialah setiap kegiatan yang mendapatkan tanah dengan cara memberikan ganti kerugian kepada yang berhak atas tanah tersebut; 2 . Pelepasan atau penyerahan hak atas tanah. Pelepasan adalah kegiatan melepaskan hubungan antara pemegang hak 
atas tanah dengan tanah yang dikuasainya dengan memberikan ganti kerugian atas dasar musyawarah.

\section{ALIH FUNGSI TANAH PERTANIAN MENJADI KAWASAN PERUMAHAN YANG DILAKUKAN MASYARAKAT TANPA PERUBAHAN RENCANA TATA RUANG WILAYAH (RTRW)}

\section{Alih Fungsi Tanah Pertanian Menjadi Kawasan Perumahan Yang Dilakukan Masyarakat}

Alih fungsi tanah merupakan kegiatan perubahan pengunaan tanah dari suatu kegiatan yang menjadi kegiatan lainnya. Alih fungsi tanah muncul sebagai akibat pembangunan dan peningkatan jumlah penduduk. Pertambahan penduduk dan peningkatan kebutuhan tanah untuk kegiatan pembangunan telah merubah strukur pemilikan dan penggunaan tanah secara terus menerus. perkembangan struktur industri yang cukup pesat berakibat terkonversinya tanah pertanian secara besarbesaran. Selain untuk memenuhi kebutuhan industri, alih fungsi tanah pertanian juga terjadi secara cepat untuk memenuhi kebutuhan perumahan yang jumlahnya jauh lebih besar. ( Adi Sasono dalam Ali Sofyan Husein, 1995,:13)

Alih fungsi tanah pertanian merupakan fenomena yang tidak dapat dihindarkan dari pembangunan. Upaya yang mungkin dilakukan adalah dengan memperlambat dan mengendalikan kegiatan alih fungsi tanah pertanian menjadi tanah non pertanian termasuk perumahan.

Secara empiris tanah pertanian yang paling rentan terhadap alih fungsi adalah sawah. hal tersebut disebabkan oleh :

(1) kepadatan penduduk di pedesaan yang mempunyai agroekosistem dominan sawah pada umumnya jauh lebih tinggi dibandingkan 
agroekosistem tanah kering, sehingga tekanan penduduk atas tanah juga lebih tinggi;

(2) daerah pesawahan banyak yang lokasinya berdekatan dengan daerah perkotaan;

(3) akibat pola pembangunan di masa sebelumnya, infrastruktur wilayah pesawahan pada umumnya lebih baik dari pada wilayah lahan kering.

(4) pembangunan prasarana dan sarana pemukiman, kawasan industri, dan sebagainya cenderung berlangsung cepat di wilayah bertopografi datar, dimana pada wilayah dengan topografi seperti itu (terutama ekosistem pertanian dominan areal persawahan).

Alih fungsi tanah pertanian yang dilakukan oleh masyarakat melalui instrumen perizinan. Permohonan izin alih fungsi tanah pertanian ke non pertanian harus memenuhi syarat, baik secara administratif maupun teknis sesuai dengtan Peraturan Pemerintah Nomor 13 Tahun 2010 Tentang Jenis dan Tarif Atas Jenis Penerimaan Negara Bukan Pajak, proses administrasi meliputi biaya, tarif penerimaan bukan pajak.

\section{Akibat Hukum Alih Fungsi Tanah Pertanian Menjadi Kawasan}

Perumahan Tanpa Perubahan Rencana Tata Ruang Wilayah (RTRW) mengenai sanksi yang harus diterima bagi pelaku alih fungsi tanah yang menyimpang dari aturan, diatur dalam Pasal 72 UndangUndang Nomor 41 Tahun 2009 tentang Lahan Pangan Berkelanjutan:

(1) Orang perseorangan yang melakukan alih fungsi Lahan Pertanian Pangan Berkelanjutan sebagaimana dimaksud dalam Pasal 44 ayat (1) dipidana dengan pidana penjara paling lama 5 (lima) tahun dan denda paling banyak Rp1.000.000.000,00 (satu miliar rupiah). 
(2) Orang perseorangan yang tidak melakukan kewajiban mengembalikan keadaan Lahan Pertanian Pangan Berkelanjutan ke keadaan semula sebagaimana dimaksud dalam Pasal 50 ayat (2) dan Pasal 51 dipidana dengan pidana penjara paling lama 3 (tiga) tahun dan denda paling banyak Rp3.000.000.000,00 (tiga miliar rupiah).

(3) Dalam hal perbuatan sebagaimana dimaksud pada ayat (1) dan ayat (2) dilakukan oleh pejabat pemerintah, pidananya ditambah $1 / 3$ (satu pertiga) dari pidana yang diancamkan.

Sedangkan sanksi yang akan diterima bagi pejabat pemerintah yang berwenang mengeluarkan izin atas permohonan alih fungsi lahan pertanian ke non pertanian, namun meberikan izin atas permohonan yang tidak sesuai dengan tata ruang, tidak memenuhi syarat-sayarat baik administratif maupun teknis dan melanggar semua ketentuan maka sesuai dengan pasal 73, pejabat tersebut dipidana dengan pidana penjara paling singkat 1 (satu) tahun dan paling lama 5 (lima) tahun dan/atau denda paling sedikit Rp1.000.000.000,00 (satu miliar rupiah) dan paling banyak Rp5.000.000.000,00 (lima miliar rupiah).

Dari ketentuan tersebut dapat diketahui bahwa perundangundangan yang digunakan Kantor Pertanahan dalam mengupayakan pengendalian alih fungsi tanah pertanian ke non pertanian, sangat lengkap, karena selain mengatur tentang pengajuan permohonan, zonasi wilayah, tim teknis, pengambilan keputusan permohonan hingga ketentuan pidana. Sehingga aturan perundang-undangan yang digunakan untuk mencegah dan atau mengendalikan alih fungsi tanah pertanian ke nopertan. 


\section{KESIMPULAN}

1. Kebijakan dalam peraturan perundang-undangan yang berkaitan dengan dengan masalah pengendalian alih fungsi tanah/lahan pertanian sudah banyak dibuat, namun demikian implementasi pelaksanaan peraturan maupun kebijakan ini dirasakan kurang efektif karena tidak didukung oleh data dan sikap proaktif yang memadai sehingga alih fungsi tanah pertanian tersebut menjadi sulit dilaksanakan. Sehinga masih banyak terjadi alih fungsi tanah pertanian menjadi perumahan

2. Akibat hukum alih fungsi Tanah pertanian menjadi kawasan perumahan bagi pelaku alih fungsi tanah yang menyimpang dari aturan, diatur dalam Pasal 72 Undang-Undang Nomor 41 Tahun 2009 tentang Lahan Pangan Berkelanjutan:

- Orang perseorangan yang melakukan alih fungsi Lahan Pertanian Pangan Berkelanjutan sebagaimana dimaksud dalam Pasal 44 ayat (1) dipidana dengan pidana penjara paling lama 5 (lima) tahun dan denda paling banyak Rp1.000.000.000,00 (satu miliar rupiah).

- Orang perseorangan yang tidak melakukan kewajiban mengembalikan keadaan LahanPertanian Pangan Berkelanjutan ke keadaan semula sebagaimana dimaksud dalam Pasal 50 ayat (2) dan Pasal 51 dipidana dengan pidana penjara paling lama 3 (tiga) tahun dan denda paling banyak Rp3.000.000.000,00 (tiga miliar rupiah).

- Dalam hal perbuatan sebagaimana dimaksud pada ayat (1) dan ayat (2) dilakukan oleh pejabat pemerintah, pidananya ditambah $1 / 3$ (satu pertiga) dari pidana yang diancamkan.

\section{DAFTAR PUSTAKA}

Adi, Susono dan Sofian Ali, Husen.1995, Ekonomi Politik Penguasaan Tanah, Jakarta: Pustaka Sinar Harapan.

Budiarto, Eko. 1997. Arsitektur dan Kota di Indonesia. Bandung Alumni.

Harsono, Boedi.2005. Hukum Agraria Indonesia, Sejarah Pembentukan Undangundang Pokok Agraria Isi Dan Pelaksanakanya, Jakarta: Djambatan.

Harsono, Boedi. 2007.Menuju Penyempurnaan Hukum Tanah Nasional. Jakarta Univesitas Trisakti. 
Harsono, Hadi. 1995. Ekonomi Politik Penguasaan Tanah. Jakarta Sinar Harapan.

Iman Muchin, Koeswahyono. 2003. Aspek Hukum Penatagunaan tanah dan Penataan ruang. Jakarta: Sinar Grafika.

Undang-undang Dasar Negara Republik Indonesia tahun 1945;

Undang-undang Nomor 5 Tahun 1960 Tentang Peraturan Pokok-pokok Agraria;

Undang-undanmg 26 tahun 2007 Tentang Penataan Ruang;

Undang-undang Nomor 41 tahun 2009 Tentang perlindumngan lahan Pertanian Pangan berkelanjutan;

Undang-undang Nomor 1 Tahun 2011 Tentang Perumahan Dan Kawasan Pemukiman;

Peraturan Nomor 12 Tahun 2012 Tentang Intensi Perlindungan Lahan Pertanian Pangan Berkelanjutan;

Peraturan Mentri Pertanian Nomor: 07/Permentan/OT.140/2/2013T

Tentang Pedoman Teknis Keteria Dan Persyaratan Kawasan, Lahan, Dan lahan cadangan Pertanian Pangan berkelanjutan 